\title{
Impact of HEdPERF on Students' Satisfaction and Academic Performance in Ghanaian Universities; Mediating Role of Attitude towards Learning
}

\author{
Stephen Banahene1, Jerry Jay Kraa', Philipine Aseye Kasu² \\ ${ }^{1}$ School of Business, Christian Service University College, Kumasi, Ghana \\ ${ }^{2}$ Faculty of Education, Christ Apostolic University College, Kumasi, Ghana \\ Email: sbanahene@csuc.edu.gh, kraaj2@yahoo.com, aseye295@gmail.com
}

How to cite this paper: Banahene, S., Kraa, J.J. and Kasu, P.A. (2018) Impact of HEdPERF on Students' Satisfaction and Academic Performance in Ghanaian Universities; Mediating Role of Attitude towards Learning. Open Journal of Social Sciences, 6, 96-119.

https://doi.org/10.4236/jss.2018.65009

Received: April 6, 2018

Accepted: May 15, 2018

Published: May 18, 2018

Copyright $\odot 2018$ by authors and Scientific Research Publishing Inc. This work is licensed under the Creative Commons Attribution International License (CC BY 4.0).

http://creativecommons.org/licenses/by/4.0/

\begin{abstract}
This study investigates the impact of HEdPERF on students' satisfaction and academic performance in Ghanaian private universities, with students' attitude towards learning as a mediator. The study was conducted on a total of 600 students selected from 6 private universities in Ghana out of which 421 responses received were useable representing $70.16 \%$ response rate. Purposive and convenience sampling techniques were adopted in selecting respondents. Questionnaire was used to collect data. Explanatory research design was also used. Stata version 13 and IBM Statistical Package for Social Sciences version 20 were the software used in data analysis. The study made use of Structural Equation Model (SEM) for data analysis and explored direct, indirect and total effect relationships. Confirmatory Factor Analysis (CFA) was used for data purification. The research found that HEdPERF has positive and statistical significant relationships with students' satisfaction, attitude towards learning and academic performance. Attitude towards learning also has positive and statistical significant relationship with students' satisfaction and academic performance. As regards the mediation effect, attitude towards learning partially mediates between HEdPERF on one hand, and students' satisfaction and academic performance on the other. This means that managers of Private Universities should consider service quality effects on students' satisfaction and academic performance with and without attitude towards learning in their strategic management.
\end{abstract}

\section{Keywords}

HEdPERF Scale, Attitude towards Learning, Performance, Academic Performance 


\section{Introduction}

The higher education sector is becoming increasingly competitive and is characterised with the presence of domestic and international educational institutions, varied forms of institutional collaborations, and students with higher levels of expectations [1]. At present, higher education has a feature of commercial competition forced by economic factors emanating from the development of global education market and reduction of government funding. The higher educational institutions need to work with industry values in the skills and abilities required from graduate students as well as students' feelings about their educational experience. [2] found that higher education sector plays an increasing role in the development of national economies. For private tertiary institutions to remain relevant to this commercial competition era, customer-orientation is most desired. Students are considered as the most essential component in quantifying quality in higher education [3]. Students serve as brand ambassadors, projecting the quality of an institution to the society. The concept of consumerism, customization and customer satisfaction influence higher education, and therefore higher educational institutions have no option but to accept students as customers. Hence, it is meaningful to consider students as brand ambassadors for knowing about service quality in higher educational institutions [3].

This study focuses on students' satisfaction and academic performance because these constructs play a significant role in churning out graduates who are potential great leaders and the required labour force for a country's economic and social development [2]. In addition, different student segments are likely to exhibit different degrees of satisfaction and academic performance due to varied attitude towards learning. This is particularly significant in the context of private higher educational sector where anecdotal evidence suggests that a greater number of students make their educational decisions on their own. In this regard, this study has the main objectives to investigate the contribution of specific dimensions of HEdPERF (Higher Education PERFormance) in improving students' satisfaction and academic performance, and also how attitude towards learning mediates HEdPERF on one hand, and students' satisfaction and academic performance on the other.

\section{Literature Review and Hypotheses}

\subsection{Introduction}

The provision of outstanding service quality is generally recognised as a vital business requirement. Service quality is not just corporate offering and a competitive weapon, it is also an essential corporate profitability and survival tool. However, service quality within the service sector has remained a complex concept. The high growth of the educational market has called for a comprehensive service quality measurement scale for higher education. In response to this, [4] developed HEdPERF (Higher Education PERFormance) out of SERVPERF model. The main purpose of HEdPERF scale was to measure service quality spe- 
cifically in the higher education sector to understand students' points of view to improve educational service delivery.

[5] used HEdPERF scale on Indian Pharmacy education and concluded that there are 4 factors that measure service quality. The factors are non-teaching aspects, teaching aspects, access and reputation. [6] also used HEdPERF scale in a study and concluded that the most significant quality dimension for measuring the quality of services in higher education institutions is "access". These authors suggested that the indicators of the HEdPERF scale should be grouped into access, reputation of the Higher Education, non-academic dimension, academic dimension, space, and study programmes. [2] have indicated that HEdPERF scale dimensions influence students' satisfaction and this in turn influences the image of an institution. [7] have emphasised that students' service quality perceptions about higher education institutions indicate a significant difference according to year of establishment of the institution, in terms of the sub-dimension of the institution's image, programmes and physical facilities. [8] adapted HEdPERF scale in a study and concluded that there are different points of view between students and professors regarding the quality of the higher education institution research. These authors concluded that "reputation" was the dimension that revealed greater dissatisfaction among students and professors.

\subsection{Service Quality and Customer Satisfaction}

Service quality has emerged to be an all-encompassing strategic force and important strategic tool for management researchers and industry practitioners. Many researchers have developed different service quality measurement scales for varied sectors. It is not also difficult to witness a number of opinions on how to accurately measure service quality to understand its essential antecedents and consequences for improving quality to achieve competitive advantage that can impact on satisfaction and higher academic performance. In line with the thinking of [9], an essential part of any academic research is to review the academic literature with scholarly interest to make contribution to such an academic debate. Table 1 shows some scales that have been developed to measure service quality in different industries.

The predominant service quality scales used by many researchers and industry practitioners are the SERVQUAL [10] and SERVPERF [12] primarily because of their generic application. In the study by Silva et al. (2017), SERVQUAL scale has been used or mentioned in 495 articles with the oldest article back from 1988 and the most recent article dates from 2016. However, the SERVQUAL and SERVPERF service quality performance indicators as adapted in higher education sector tend to measure activities rather than measure the quality of students' educational experience [16]. To [4], the generality of the SERVQUAL and SERVPERF scales is still hazy when they are applied to service quality at higher education institutions. As a result, Abdullah has developed a new measurement 
Table 1. Service quality measurement scales developed for industries.

\begin{tabular}{ccc}
\hline Author & Scale developed & Industry \\
\hline$[10]$ & SERVQUAL & General \\
{$[11]$} & LODGSERV & Hospitality \\
{$[12]$} & SERVPERF & General \\
{$[13]$} & LODGQUAL & Hospitality \\
{$[1]$} & RSQS Retail & Retail \\
{$[4]$} & HEdPERF* & Higher education \\
{$[14]$} & HEDQUAL & Higher education \\
{$[15]$} & CUL-HEdPERF & Higher education \\
\hline
\end{tabular}

*service quality measure used in the study.

scale called HEdPERF that was based on the SERVPERF scale, which considered the specific determinants of service quality in higher education. [14] have pointed out that, HEdPERF is the most developed scale in the literature to measure service quality in higher education. Since 2014, some researchers have used HEdPERF scale to measure service quality but they remain few when compared with SERVQUAL and SERVPERF [17]. It is therefore interesting to undertake research on HEdPERF scale on Private University students' satisfaction and academic performance to meet academic interest and managerial performance. In this same regard, the mediating role of attitude towards studies is necessary for consideration in terms of academic and managerial pursuit.

Most of the research works in higher education institutions have produced confirmation that service quality leads to students' satisfaction [18] [19] but review of literature highlights the inherent challenges in measuring service quality and customer satisfaction. Fundamentally, most of the models of customer satisfaction often compare students' expectations to the observed service quality experience that are known as service quality gap. However, available evidence clarified that the application of performance minus expectation has given positive effect to students' perceptions of service quality and with that, service quality directly affects students' satisfaction. Notwithstanding, higher education institutions offer high service quality in all aspects in order to gratify students who are their major customers. This is so because satisfaction has been revealed as the customers' gratification feedback and service excellence is noted as the key performance measurement for excellence in the education industry. Overall perceived service quality is a preliminary to contentment and it is also a major prerequisite for creating and maintaining students' satisfaction and retaining them [20]. It has also been found that there is continuous growth in the study of service quality and customer satisfaction as the background of customer behavioural intentions. This paper is influenced by the fact that service quality does not on its own lead to satisfaction [21] and higher academic performance, but can be affected by students' attitude towards learning. It is appreciated that ser- 
vice quality and customer satisfaction have relationship to market share and customer retention [22].

[23] revised the SERVQUAL measurement scale and analytically tested the health care service of Chiropractic Care to find the correlation between service quality and patients' fulfillment. The findings indicated that service quality should be treated as a precursor of customer satisfaction. [24] studied customers of fast-food restaurant in America and Latin America and found that cultural background had a relationship between service quality and customer satisfaction. [25] have also found that service quality and customer satisfaction had a very high correlation. In the work of [26], service quality is important factor for satisfaction among youngsters in Private Colleges in Faisalabad, Punjab and Pakistan. In their study, all the perspectives of service quality were found to be positively correlated but empathy showed negative relationship with service quality and customer satisfaction. These studies point to the fact that service quality positively affects customer satisfaction. The study has hypothesized that:

$\mathrm{H}_{1}$ : Service quality positively and significantly affects student's satisfaction.

\subsection{Students' Academic Performance}

Students' academic performance measurement has received considerable attention in different research works and has become a challenging topic in academic literature. The students' academic performance plays an important role in creating the finest quality alumni who provides material support and play ambassadorial role for academic institutions. Good academic performance can lead to lower marketing cost, enhance opportunity for brand extension and increased market shares. Academic performance can also promote favourable word of mouth and greater resistant among loyal students to competitive strategies which can lead to lower levels of price sensitivity among students and parents. Students' academic performance is also an important antecedent to the design and implementation of academic policies which aim to improve quality in education by changing attitude of students towards learning [27]. However, despite tremendous interest in students' satisfaction and academic performance, very little empirical research has explored how these constructs are affected by service quality dimensions.

Many research works measure students' academic performance by using $\mathrm{Cu}$ mulative Grade Point Average (CGPA), Grade Point Average (GPA) or the latest results as a convenient summary measure of their students' academic performance. Some researchers have argued that, the GPA gives a better measurement insight into the relative level of performance of individual and different group of students. Other researchers assessed the performance of students through the previous year's results or an outcome of a particular course [28] [29]. This approach treats the measurement of students' academic performance as an event. Students' academic performance can be better looked at as a continuous process 
in the teaching and learning system where the learner accumulates an incremental skill set to deal with academic issue.

Several studies have been conducted to find out the factors that affect academic performance of students. Some researchers have demonstrated that students' academic performance depends on factors like psychological, economic, social, personal and environmental factors. [15] has indicated that the most significant factor with positive outcome on students' academic performance is competence in English as it builds students confidence. [27] have found that academic activities of students, perception of their adapting strategies and background qualities have connection to their compound scores. [30] have noted that students' academic performance relies on socioeconomic variables such as students' participation in class, family pay, teacher-student ratio, presence of qualified teachers, and gender of the student.

A number of research works have also focused on factors that affect students' academic performance in higher education. [31] examined the relationship between college experience and academic performance among minority students in American higher education. The authors found that some background variables such as adequate financial resources positively associated with students' academic performance. They also found that academic and social integration variables impacted on students' GPAs. [32] conducted research to examine the role of satisfaction in the performance and retention of fresh students in Mississippi State University Pathfinders Survey. The results of the ANOVA indicated that five out of six satisfaction dimensions were significantly associated with students' academic performance. Students who had higher satisfaction were performing better academically in comparison to those who reported lower satisfaction. This study also suggests that service quality can affect academic performance. Hence, this study hypothesis that:

$\mathrm{H}_{2}$ : Service quality positively and significantly affects academic performance.

\subsection{Attitude towards Learning Relationship with Academic Performance and Satisfaction}

The behavioural theory used in the review of attitude towards learning relationship with academic performance and satisfaction constructs is based on the theory of reasoned action and theory of planned behaviour. The theory of reasoned action is about the relationship between the attitude and behaviour. According to [33], human usually behave in a conscious manner, considering all available information. Explicitly or implicitly human also take the implication of their actions into account. Human attitude affects behaviour through one decision-making process which is done carefully and reasonably. Theory of planned behaviour explains that attitude towards behaviour is affected by the belief that the behaviour will lead to the desired or undesirable results. Perceived behavioural control is determined by past experiences and individual estimation of how difficult or easy it is to perform the behaviour in question. Attitude to- 
wards specific behaviours, subjective norms, and perceived behavioural control interact and becomes a determinant for the intention, which in turn will determine whether the behaviour or action can be done. In the moderating role of attitude towards learning, service quality relationship with academic performance and satisfaction can be influenced in line with behavioural theory.

Several scholars have attempted to define the word "attitude" in different ways, however, there is no agreed definition so far for attitude. [34] claimed that attitude of a person is positive or of negative attributes to anything. [35] defined attitude as a person persistent way of behaving in a particular way. [36] has given new dimension to attitude concept by dividing into three elements, namely: cognitive, evaluative and behavioural and they all work together. An attitude is a relatively enduring organization of beliefs, feelings, and behavioural tendencies towards socially significant objects, groups, events or symbols [37]. The attitude towards learning, reflecting the model of attitudes, is understood as beliefs, thoughts and opinions about learning in it, emotions and a relationship towards learning built upon feelings, and a tendency to behave in accordance with favourable and unfavourable experiences with learning [38]. Attitude on the other hand is defined as the like or dislike of a course or subject. [34] and [39] also viewed attitudes as an expression of inner feelings that reflect whether an individual is favourably or unfavourably disposed to some "attitude object". An attitude is an internal disposition to evaluate in positive or negative terms an object, which is accompanied by affective, cognitive, and behavioral responses [40].

Some researchers have examined the role students' study habits and their attitudes towards learning have on academic performance. [41] have scrutinized the value of inculcating proper study habits in students, to help achieve a higher academic performance and found that study habits and students' performance had a very positive relationship. This indicates that students' academic performance can improve only when they develop proper learning habits. [42] have found that non-cognitive factors like study habit, skill and study motivation, among other attitudinal constructs, accounted for incremental variance in academic performance beyond standardized tests and previous grades. Similarly, [32] found a significant and positive relationship between academic achievement and study habits. Their study further revealed that habits such as reading, concentration, note-taking and preparation for examination also have a positive and significant relationship with academic achievement. In the study of Sarwar, Bashir [43], it came to bare that a significant correlation between academic performance and student attitudes exists. This study therefore hypothesized that:

$\mathrm{H}_{3}$ : Attitude towards learning positively and significantly affects academic performance.

Learning is an individual action which confronts the learner with the risk of going to an unknown place in the end. For most of the teachers, a good student is the one who is eager to learn and has positive attitudes towards learning. According [44], a student who is motivated to learn become more satisfied and 
tend towards the thinking skills. Learning is basically an individual performance. For that reason, positive or negative attitudes towards learning are valuable for the success of every learning situation. Attitude is a tendency which is attributed to individuals and creates ideas, feelings and behaviours about a psychological object in an orderly manner [45]. While the positive attitudes serve a better comprehension for the learners, attitude towards learning makes students more open to learning, increases their satisfaction from learning and enhance their academic performance. However, it is important that the intrinsic motivators of the learner, such as satisfaction, high academic performance, and the learners' sense of wonder all support the process of learning. This study hypothesized that:

$\mathrm{H}_{4}$ : Attitude towards learning has positive and significant relationship with students' satisfaction.

Attitude could be defined as a consistent tendency to react in a particular way often positively or negatively toward a given matter or social object. Students have attitude towards learning, but not all have the same attitude towards it. Some students' attitudes propel them along, helping them to achieve high academic performance and become satisfied. Others have attitudes that slow them down or stop them from learning [46]. This means that individuals are not born with attitudes but they learn them. From early childhood, individuals begin to form attitudes through experience and observation. Through social contacts, persons acquire attitude by watching and imitating. A person could also develop attitudes through operant conditioning through service quality. It is on the basis of this operant conditioning that the relationship between service quality, and satisfaction and academic performance through students' attitude towards learning could be explained [47].

Students with positive attitude towards learning make significantly better academic achievement than their counterparts with negative attitude towards school. Good attitude towards learning could be reinforced in line with specifications in operant conditioning theory of learning (as cited by [48]. According to [49], attitude towards learning is a psychological construct that depicts an individual's behaviours, feelings, expression of favourable or unfavourable affection and judgments for educational experiences. Attitude towards learning, like other constructs, is intrinsically related to other psychological traits such as students' satisfaction and academic performance. [48] study showed that academic performance attitude significantly alters the effect of competitive sports participation on academic performance. In other words, academic performance attitude affects the influence of competitive sports participant on academic performance. This study hypothesized that:

$\mathrm{H}_{5 \mathrm{a}}$ : Attitude towards learning has full mediation effect on the relationship between service quality, and academic performance.

$\mathrm{H}_{5 b}$ : Attitude towards learning has full mediation effect on the relationship between service quality, and students' satisfaction. 


\section{Methodology and Measurement of Construct}

\subsection{Methodology}

This study is an applied research in terms of its objectives, it is quantitative in terms of data collection and analysis, and it is explanatory research design to establish causal relationships among service quality, satisfaction, academic performance, and attitude towards studies. The statistical community of this study consists of students in the private universities in the Ashanti Region of Ghana. Samples of 600 students were selected from six private universities with 100 from each institution. [50] has stated that, as small as of 30 samples is enough for successful statistical study if the characteristics of the respondents are homogenous in nature hence a sample of 600 is more than enough to be a representative of students from 6 private universities. Convenient and purposive sampling techniques were adopted in selecting respondents. With purposive sampling, the study chooses sampled units who, by the researcher judgment, meet the specific purpose of the survey. The students in the private universities in Ghana were selected from various area of specialization. With respect to convenience sampling the respondents are simply those who are easily available or convenient for data collection. Thus, most university students that are available for the study were intercepted on their lecture halls and hostel to participated in the study. The study used questionnaires in collecting primary data from the respondents. The questionnaires were closed ended on a 7-point Likert scale ranging from very strongly disagree [1] to very strongly agree [7] to the statements. Questions from HEdPERF dimensions, attitude towards learning, student satisfaction and academic performance variables were adapted and amended to suit the Ghanaian situation. The variables the meet the fit indices after the CFA results were presented in Table 2 and Table 3 . The study made use of IBM [20] Statistical Package for Social Science (SPSS) and Stata (version 13) in conducting the analysis. Confirmatory Factor Analysis (CFA) was done after which problematic indicators that loaded poorly were taken out. Structural Equation Model (SEM) was the main tool used to estimate the relationships. The study control for programme of study, age of respondents and the institution attended in order to conserve statistical power.

\subsection{Measurement of Research Constructs}

The HEdPERF dimensions which measured service quality was adapted from [4]. These variables were amended to suit the Ghanaian private university situation. The dimensions are non-academic aspects, academic aspects, reputation, access and programme issues. The students' satisfaction and academic performance scales were also adapted from [3] and Shapiro [51] respectively. As regards attitude towards studies, the scale was adapted from [52]. In all, 36 questions were developed for HEdPERF but after the CFA purification, 19 variables were selected based on the fit indices. Attitude towards studies was also adapted from the works of [52]. 12 questions were developed from these authors but after 
the CFA purification, 5 variables were selected based on the fit indices. Variables measuring academic performance were adapted from [51]. 10 questions were

Table 2. Validity and reliability test using CFA.

\begin{tabular}{|c|c|c|c|c|c|c|c|c|}
\hline Measures and Items & Retained & Factor Loadings & $\mathrm{T}$ values & Cronbach's Alpha & $\begin{array}{l}\text { Construct } \\
\text { Validity }\end{array}$ & Highest VIF & AVE & $\begin{array}{l}\text { Highest } \\
\text { Correlation }\end{array}$ \\
\hline \multirow{5}{*}{$\begin{array}{c}\text { Non-Academic } \\
\text { Aspect }\end{array}$} & Item 1 & 0.6908055 & 19.94 & \multirow{5}{*}{0.7837} & \multirow{5}{*}{0.792} & \multirow{5}{*}{1.59} & \multirow{5}{*}{0.652} & \multirow{5}{*}{0.5743} \\
\hline & Item 2 & 0.7275884 & 22.05 & & & & & \\
\hline & Item 3 & 0.6359725 & 17.05 & & & & & \\
\hline & Item 4 & 0.6077025 & 15.60 & & & & & \\
\hline & Item 5 & 0.5806738 & 14.44 & & & & & \\
\hline \multirow{4}{*}{ Academic Aspect } & Item 1 & 0.5436257 & 11.56 & \multirow{4}{*}{0.6689} & \multirow{4}{*}{0.752} & \multirow{4}{*}{2.26} & \multirow{4}{*}{0.634} & \multirow{4}{*}{0.6013} \\
\hline & Item 2 & 0.5202072 & 10.73 & & & & & \\
\hline & Item 3 & 0.8139375 & 17.43 & & & & & \\
\hline & Item 4 & 0.4620713 & 9.59 & & & & & \\
\hline \multirow{3}{*}{ Reputation } & Item 1 & 0.6839061 & 17.52 & \multirow{3}{*}{0.7235} & \multirow{3}{*}{0.760} & \multirow{3}{*}{2.07} & \multirow{3}{*}{0.727} & \multirow{3}{*}{0.6446} \\
\hline & Item 2 & 0.7811469 & 20.56 & & & & & \\
\hline & Item 3 & 0.6034162 & 14.37 & & & & & \\
\hline \multirow{3}{*}{ Access } & Item 1 & 0.4918744 & 10.53 & \multirow{3}{*}{0.7067} & \multirow{3}{*}{0.831} & \multirow{3}{*}{1.45} & \multirow{3}{*}{0.729} & \multirow{3}{*}{0.5051} \\
\hline & Item 2 & 0.653702 & 13.98 & & & & & \\
\hline & Item 3 & 0.8909986 & 17.19 & & & & & \\
\hline \multirow{4}{*}{ Programme Issues } & Item 1 & 0.7504859 & 23.82 & \multirow{4}{*}{0.7990} & \multirow{4}{*}{0.802} & \multirow{4}{*}{1.99} & & \\
\hline & Item 2 & 0.6878366 & 20.11 & & & & & \\
\hline & Item 3 & 0.7017046 & 20.80 & & & & 0.704 & 0.3900 \\
\hline & Item 4 & 0.6867334 & 19.92 & & & & & \\
\hline & Item 1 & 0.6177804 & 15.90 & & & & & \\
\hline Students & Item 2 & 0.6426371 & 16.98 & 0 7750 & 0786 & 100 & 0600 & 05675 \\
\hline Satisfaction & Item 3 & 0.7188582 & 20.97 & & & & & \\
\hline & Item 4 & 0.7487615 & 22.48 & & & & & \\
\hline & Item 1 & 0.6348772 & 16.68 & & & & & \\
\hline Academic & Item 2 & 0.768365 & 23.05 & & & & & $0-57$ \\
\hline Performance & Item 3 & 0.6567591 & 17.38 & 0.1002 & $0 . / 82$ & 1.00 & $0.0 / 9$ & $0.20 / 2$ \\
\hline & Item 4 & 0.6091828 & 15.53 & & & & & \\
\hline & Item 1 & 0.6886163 & 21.62 & & & & & \\
\hline & Item 2 & 0.7207222 & 23.80 & & & & & \\
\hline $\begin{array}{l}\text { Attitude towards } \\
\text { Learning }\end{array}$ & Item 3 & 0.8254607 & 33.15 & 0.8276 & 0.841 & 1.26 & 0.686 & 0.5682 \\
\hline & Item 4 & 0.6493537 & 19.01 & & & & & \\
\hline & Item 5 & 0.5439614 & 13.69 & & & & & \\
\hline
\end{tabular}

Source: Author Field work, 2016. 
Table 3. Variables measuring the construct.

\begin{tabular}{|c|c|c|c|}
\hline Items & Variables & Factor Loadings & $\mathrm{T}$ \\
\hline & Non-Academic Aspect & & \\
\hline 1 & There is systematic and reassurance in solving problems & 0.6908055 & 19.94 \\
\hline 2 & My University keeps to its promises & 0.7275884 & 22.05 \\
\hline 3 & My University is dependable in all times & 0.6359725 & 17.05 \\
\hline 4 & My University responds to request promptly & 0.6077025 & 15.60 \\
\hline \multirow[t]{2}{*}{5} & My University provides services within a reasonable time periods & 0.5806738 & 14.44 \\
\hline & Academic Aspect & & \\
\hline 1 & I gain a lot of knowledge in course content in my University & 0.5436257 & 11.56 \\
\hline 2 & There is always feedback from academic assignments & 0.5202072 & 10.73 \\
\hline 3 & There is excellent quality programmes & 0.8139375 & 17.43 \\
\hline \multirow[t]{2}{*}{4} & There is sufficient consulting time for academic issues & 0.4620713 & 9.59 \\
\hline & Reputation of university & & \\
\hline 1 & I feel secured dealing with my University & 0.6839061 & 17.52 \\
\hline 2 & I have total trust with my University & 0.7811469 & 20.56 \\
\hline \multirow[t]{2}{*}{3} & My school operates in religious-like manner & 0.6034162 & 14.37 \\
\hline & Access & & \\
\hline 1 & The non-academic staff are approachable in times of need & 0.4918744 & 10.53 \\
\hline 2 & It is easy to contact academic staff for information & 0.653702 & 13.98 \\
\hline \multirow[t]{2}{*}{3} & It is easy to contact non-academic staff for information & 0.8909986 & 17.19 \\
\hline & Programme Issues & & \\
\hline 1 & The syllabus is flexible & 0.7504859 & 23.82 \\
\hline 2 & Prompt dealing with complaints with programme issues & 0.6878366 & 20.11 \\
\hline 3 & There are excellent academic programmes & 0.7017046 & 20.80 \\
\hline \multirow[t]{2}{*}{4} & There are available information on programmes & 0.6867334 & 19.92 \\
\hline & Students Satisfaction & & \\
\hline 1 & I am satisfied with the university learning services & 0.6177804 & 15.90 \\
\hline 2 & Overall, I am happy with the specialization I have chosen. & 0.6426371 & 16.98 \\
\hline 3 & I am happy with the academic work of the University & 0.7188582 & 20.97 \\
\hline \multirow[t]{2}{*}{4} & I am satisfied with the lecturers that impact knowledge & 0.7487615 & 22.48 \\
\hline & Academic Performance & & \\
\hline 1 & I am consistent with quality of my academic work & 0.6348772 & 16.68 \\
\hline 2 & I quickly learn new materials apart from my course of study & 0.768365 & 23.05 \\
\hline 3 & My grading point merits my efforts & 0.6567591 & 17.38 \\
\hline \multirow[t]{2}{*}{4} & I have improved my reading skills & 0.6091828 & 15.53 \\
\hline & Attitude towards Learning & & \\
\hline 1 & I consider learning to be enjoyable & 0.6886163 & 21.62 \\
\hline 2 & I continue with difficult problems even if I can't do it & 0.7207222 & 23.80 \\
\hline 3 & I show interest in dealing with difficult subjects & 0.8254607 & 33.15 \\
\hline 4 & I have no troubles learning concepts & 0.6493537 & 19.01 \\
\hline 5 & I enjoy working with others to solve problems & 0.5439614 & 13.69 \\
\hline
\end{tabular}


developed from these authors but after the CFA purification, 4 variables were selected based on the fit indices. The students' satisfaction scale was adapted from [3] academic satisfaction scale. 12 questions were developed from the works of the author but after the CFA purification, 4 variables were selected based on the fit indices.

\subsubsection{Validity and Reliability Assessment}

To evaluate the reliability and validity of the HEdPERF dimensions, students' satisfaction, academic performance and attitude towards learning constructs, CFA was run and refined using Stata 13 to show a good fit. The final CFA results show a good fit to the data. After purification, numerous items were removed from the models because they loaded poorly on the factor. The criterion used was 0.4 as advised by [53]. Factor loadings for each construct are significant at $5 \%$ for the variables that supports convergent validity of the measures [53]. Reliability was assessed using three indicators of Convergent and Discriminant Validity, Composite Reliability, Average Variance Extracted (AVE), and Highest Shared Variance (HSV). All the AVE was greater as compared to the shared variances between constructs, meaning that satisfactory discriminant validity was achieved [54]. In all the constructs, reliability assessment generated indices that were greater than the recommended 0.70 cutoff [55]. By using [54] procedure, discriminant validity of each construct was assessed by examining whether the $\mathrm{AVE}$ for each construct was higher than the shared variances (i.e., squared correlations) of construct used. Discriminant validity is demonstrated for each construct for both samples, as the AVE for each construct is greater than the HSV between the constructs. Cronbach alpha was also used to assess internal consistency among the variables. Alpha values of close to and above 0.7 were achieved for each construct used. Table 2 and Table 4 show CFA results and fit indices respectively.

\subsubsection{Correlation Matrix}

To check whether the strength of correlation among the variables will affect further

Table 4. Measurement invariance tests (Fit Indices).

\begin{tabular}{ccccccc}
\hline Dimension/Construct & chi-square & degrees of freedom & p-value & RMSEA & CFI & SRMR \\
\hline Non-Academic & 6.04 & 5 & 0.3027 & 0.022 & 0.998 & 0.017 \\
Academic & 1.68 & 2 & 0.4306 & 0.000 & 1.000 & 0.012 \\
Reputation & 8.51 & 2 & 0.0142 & 0.089 & 0.979 & 0.026 \\
Access & 0.00 & 0.00 & 0.00 & 0.000 & 1.000 & 0.000 \\
Programme Issues & 2 & 3.36 & 0.1867 & 0.041 & 0.997 & 0.012 \\
Students Satisfaction & 2 & 3.31 & 0.1908 & 0.040 & 0.997 & 0.013 \\
Academic Performance & 5 & 11.39 & 0.0441 & 0.056 & 0.985 & 0.025 \\
Attitude towards Learning & 5 & 3.96 & 0.5557 & 0.000 & 1.000 & 0.012 \\
\hline
\end{tabular}

Notes: $\chi^{2}=$ Chi-square d.f. $=$ Degree of freedom; $\chi^{2} / \mathrm{d} . \mathrm{f}=$ normed Chi-square; RMSEA $=$ Root mean stan dard error of approximation; CFI = Comparative fit index; SRMR = Standardized mean square residual; TLI $=$ Tucker Lewis Index 
statistical analysis; a multicollinearity test was run using the Pearson correlation statistics. For robustness, it is recommended that the correlation statistics should not exceed 0.7 [56]. The correlation result shows positive and significant relationship among the variables. Correlation is significant at 0.01 . It can therefore be concluded that multicollinearity is not a serious threat in this study. The correlation matrix is shown in Table 5 .

\section{Analysis and Discussion}

\subsection{Demographic Information}

The work involved a sample of 600 students out of which 412 responses were received. It was found that most of the respondents are females, (236) representing $57.3 \%$ and 176 representing $42.7 \%$ are males after a descriptive summary was done. Even though the males are more than the females in tertiary institutions, more females participated in the study. Looking at the age distribution of the respondents, it was observed that the majority of the respondents, 220 (representing 53.4\%) fall within 20 - 30-year age bracket. This is followed by respondents whose ages are between 31 - 40 years (91) representing $22.1 \%$. A total of 69 respondents representing $16.7 \%$ fell under 20 years and only one matured student who is above 50 years. The general observation is that, youngest and vibrant youths are devoting much time and effort to improve their education and hence working and attending school at the same time. On the whole, students studying business related courses such as Accounting, Marketing, Human Resource Management, and Procurement studies dominated student's enrolment in private universities in Ghana. On the programme of study, 331 respondents are studying business related courses representing $56.1 \%$ whiles 181 respondents representing $43.9 \%$ are pursuing other tertiary courses. Table 6 shows demographic characteristics of the respondents.

Table 5. Correlation matrix.

\begin{tabular}{ccccccccc}
\hline & NAA & AA & REP & ACC & PI & SAT & PERF & ATL \\
\hline NAA & 1 & & & & & & \\
AA & $0.5743^{* *}$ & 1 & & & & & \\
REP & $0.5002^{* *}$ & 0.6013 & 1 & & & & & \\
ACC & $0.3495^{*}$ & $0.4085^{* *}$ & $0.4788^{* *}$ & 1 & & & & \\
PI & $0.4705^{*}$ & $0.6207^{*}$ & $0.5944^{*}$ & $0.5051^{*}$ & 1 & & & \\
SAT & $0.3610^{* *}$ & $0.5643^{* *}$ & $0.6446^{* *}$ & $0.4254^{* *}$ & 0.5903 & 1 & & \\
PERF & $0.3275^{* *}$ & $0.5256^{*}$ & $0.4838^{*}$ & $0.3776^{* *}$ & $0.5046^{*}$ & $0.5675^{*}$ & 1 & \\
ATL & $0.3588^{* *}$ & $0.4974^{* *}$ & 0.5682 & $0.4312^{* *}$ & $0.4913^{*}$ & $0.5342^{*}$ & $0.4784^{*}$ & 1 \\
\hline
\end{tabular}

NAA = Non-Academic Aspect; AA = Academic Aspect; REP = Reputation of university; ACC = Access; PI $=$ Programme Issues; SAT $=$ Students Satisfaction; PERF $=$ Academic Performance; ATL $=$ Attitude towards Learning. 


\subsection{Relationship between HEdPERF Dimensions and Students' Satisfaction and Academic Performance}

The study analysed the relationship between HEdPERF dimensions on one hand, and students' satisfaction and academic performance on the other. Figure 1 shows the structural equation model that indicates the relationships.

Table 6. Demographic information.

\begin{tabular}{ccc}
\hline Variables & Frequency & Percentage (\%) \\
Gender & 176 & 42.7 \\
Male & 236 & 57.3 \\
Female & & \\
Age distribution & 69 & 16.7 \\
under 20 years & 220 & 53.4 \\
20 - 30 years & 91 & 22.1 \\
$31-40$ years & 31 & 7.5 \\
41 - 50 years & 1 & 0.2 \\
51 years and above & & \\
Programme of Study & 231 & 56.1 \\
Business Administration & 181 & 43.9 \\
Others course & &
\end{tabular}

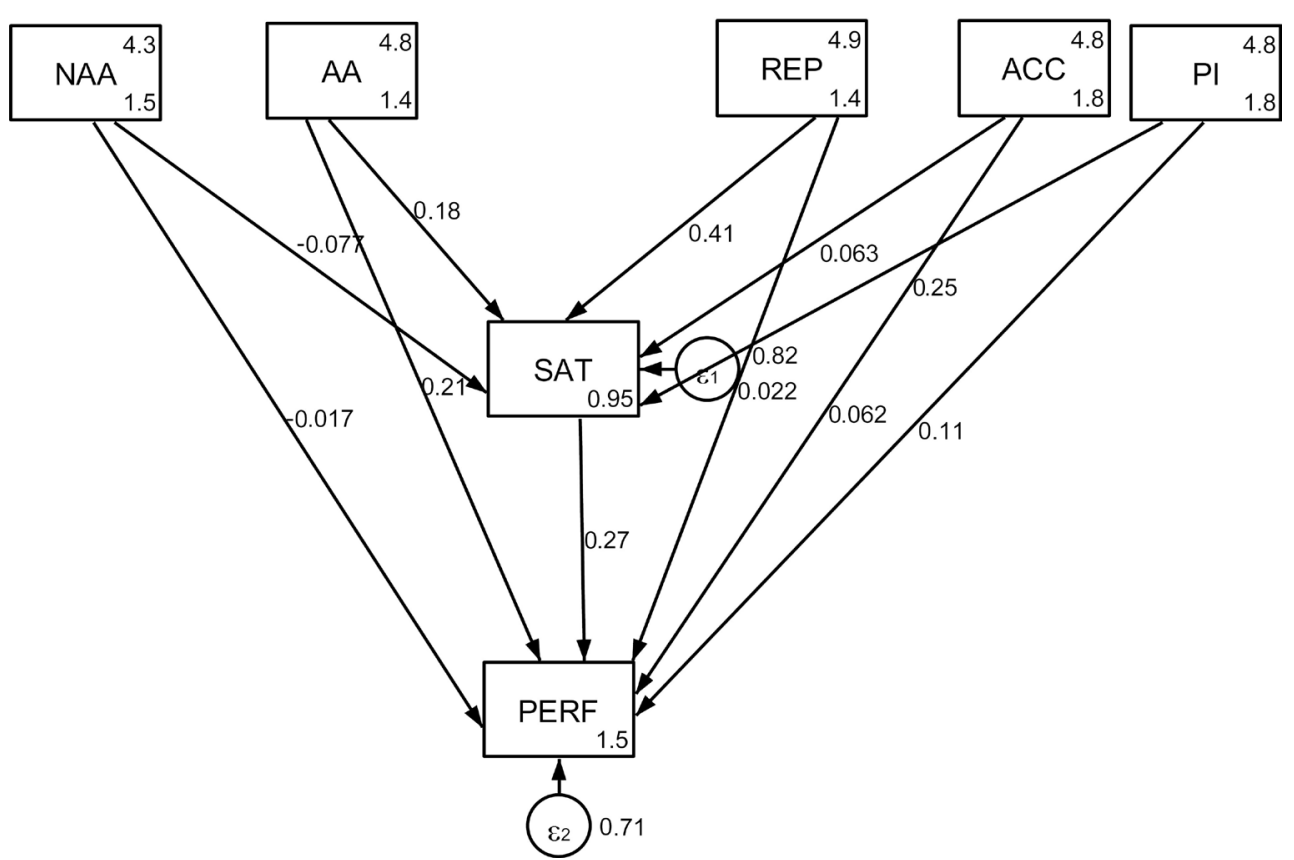

$\mathrm{NAA}=$ Non-Academic Aspect; AA = Academic Aspect; REP = Reputation of University; ACC = Access; PI = Programme Issues; $\mathrm{SAT}=$ Students Satisfaction; PERF $=$ Academic.

Figure 1. The relationship between HEdPERF dimensions and students' satisfaction and academic performance. 
Figure 1 shows that four of the HEdPERF dimensions have positive relationship with students' satisfaction. These dimensions are academic aspect, reputation, access and programme issues. However, further analysis shows that academic aspect, reputation and programme issues have positive and significant relationship with students' satisfaction. Non-academic aspect has negative relationship with students' satisfaction. Access has positive relationship with students' satisfaction but not statistically significant. These results imply that, academic aspect, reputation and programme issues are statistically significant making a unique prediction to explaining students' satisfaction when the variance in the model is controlled for. However, an improvement in access has positive impact on students' satisfaction but the effect is not statistically significant. The negative relationship between non-academic aspect and students' satisfaction also means that an improvement in non-academic issues has dire consequences on students' satisfaction, and as such not statistically significant.

As regards HEdPERF dimensions relationship with academic performance, non-academic aspect again has negative relationship with academic performance and it is not statistically significant. The academic aspect and programme issues have positive relationship with academic performance and are statistically significant. The reputation and access dimensions have positive relationships with academic performance but they are not statistically significant. These findings also mean that academic aspect and programme issues can predict improvement in students' academic performance. Table 7 shows the statistical information on HEdPERF dimensions' relationship with students' satisfaction and academic performance.

Table 7. HEdPERF dimensions' relationship with students' satisfaction and academic performance.

\begin{tabular}{|c|c|c|c|c|c|}
\hline Dimension & Coefficient & OIM Std Err & $\mathrm{Z}$ & P-Value & 95\% Conf. \\
\hline \multicolumn{6}{|l|}{ Students' Satisfaction } \\
\hline Non-academic & -0.0773044 & 0.0465167 & -1.66 & 0.097 & -0.1684756 \\
\hline Academic & 0.1835234 & 0.0576548 & 3.18 & 0.001 & 0.070522 \\
\hline Reputation & 0.4137541 & 0.053665 & 7.71 & 0.000 & 0.3085726 \\
\hline Access & 0.063491 & 0.0394763 & 1.61 & 0.108 & -0.013881 \\
\hline Programme issues & 0.2470384 & 0.0473694 & 5.22 & 0.000 & 0.154196 \\
\hline \multicolumn{6}{|l|}{ Academic Performance } \\
\hline Non-academic & -0.0173047 & 0.0433276 & -0.40 & 0.690 & -0.1022251 \\
\hline Academic & 0.2128086 & 0.0541771 & 3.93 & 0.000 & 0.1066235 \\
\hline Reputation & 0.0218809 & 0.0532919 & 0.41 & 0.681 & -0.0825693 \\
\hline Access & 0.0624428 & 0.036762 & 1.70 & 0.089 & -0.0096094 \\
\hline Programme issues & 0.1056816 & 0.0454029 & 2.33 & 0.020 & 0.0166935 \\
\hline
\end{tabular}




\subsection{Relationship between HEdPERF, Student Satisfaction, Attitude towards Learning and Academic Performance}

The findings of the study show a positive and statistically significant relationship among HEdPERF, students' satisfaction, attitude towards learning and academic performance constructs. This implies that, HEdPERF as a measure of service quality at higher education favourably affects students' satisfaction and academic performance. This has supported $\mathrm{H}_{1}$ and $\mathrm{H}_{2}$. Attitude towards learning also has positive relationship between academic performance and students' satisfaction. These findings also support $\mathrm{H}_{3}$ and $\mathrm{H}_{4}$ respectively. Figure 2 shows the structural relationships among HEdPERF, students' satisfaction, attitude towards learning and academic performance.

These findings from Ghana's higher education context show that service quality positively and significantly affect students' satisfaction. This means that when service quality improves students' satisfaction goes up. This finding supports the work of [26] among students in Private Colleges in Faisalabad. The findings on the positive and significant relationship between service quality and academic performance support the study of [32] among students in Mississippi State University.

In addition, students' attitude towards learning can predict students' satisfaction and academic performance when the variance in the model is controlled for. The finding supports the work of [41] which looked at the effectiveness of inculcating proper study habits in students, with the aim of achieving higher

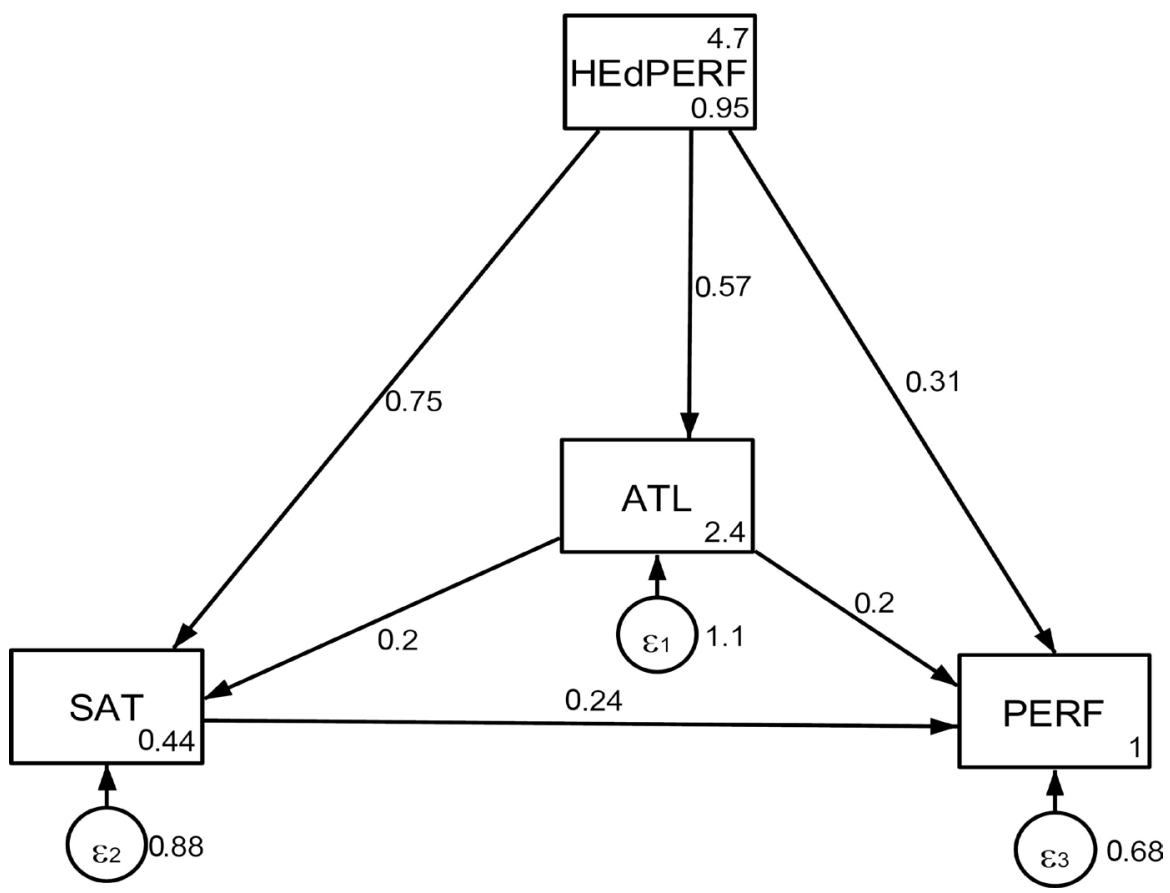

HEdPERF $=$ Higher Education PERFormance; SAT $=$ Students Satisfaction; PERF = Academic Performance; ATL = Attitude Towards Learning.

Figure 2. Structural relationships among HEdPERF, students' satisfaction, attitude towards learning and academic performance. 
academic performance, revealed a high correlation between students' academic performance and study habits. The finding again corresponds with the findings of [57] that also found positive and significant relationship between study habits and academic performance. In the study of [43], it was revealed that a significant relationship between students' attitude and academic performance exists. The implication for Ghanaian students is that, if positive attitude is developed towards learning, the resultant effect is improved academic performance. Table 8 shows the statistical information on the relationship among HEdPERF, attitude towards learning, students' satisfaction and academic performance.

\subsection{Mediating Role of Attitude towards Learning between HEdPERF, and Students' Satisfaction Academic Performance}

Mediation seeks to identify and explicate the mechanism that underlies an observed relationship between an independent variable (HEdPERF) and a dependent variable (Students' Satisfaction and Academic Performance) via the inclusion of a third explanatory variable, known as the mediator (Attitude Towards Learning). Rather than hypothesizing a direct causal relationship between the service quality on one hand, and students' satisfaction and academic performance on the other, a mediation model hypothesizes that the service quality causes the mediator variable (attitude toward learning), which in turn causes the dependent variables (students' satisfaction and academic performance). Having certified the measurement instrument's suitability for statistical analysis, the structural equation modeling was used to explore the relationship between the variables. Specifically, to ascertain whether attitude towards learning performed any mediating role in the relationship between students' satisfaction and academic performance. [58] believed that, there are many ways that can be used to test hypotheses with respect to establishing mediation. One of the commonly used method that was adopted has to do with causal steps strategy, propounded by [59]. Thus, the investigator estimates the paths of the model, using Ordinary Least Square [OLS] regression or SEM, that ascertain the degree to which many criteria are met. [59] proposed some important but not sufficient conditions which must be met in order to claim mediation is happening. For mediation

Table 8. Relationship among HEdPERF, attitude towards learning, students' satisfaction and academic performance.

\begin{tabular}{ccccccc}
\hline Independent variable & Coef. & OIM Std. Err & $\mathbf{Z}$ & $\mathbf{P}>|\mathbf{z}|$ & $95 \%$ Conf. & Dependent variable \\
\hline HEdPERF & 0.3059591 & 0.0572739 & 5.34 & 0.000 & 0.1937044 & Academic Performance \\
HEdPERF & 0.5731455 & 0.0530769 & 10.80 & 0.000 & 0.4691166 & ATL \\
HEdPERF & 0.7486839 & 0.05347 & 14.00 & 0.000 & 0.6438845 & Students' Satisfaction \\
ATL & 0.2008102 & 0.438166 & 4.58 & 0.000 & 0.1149312 & Students' Satisfaction \\
ATL & 0.2005642 & 0.0396059 & 5.06 & 0.000 & 0.1229381 & Academic Performance
\end{tabular}

ATL $=$ Attitude Towards Learning. 
conditions to exist the independent variable should significantly relate to the mediator and the mediator should also significantly relate to the dependent variable. The relationship between the independent variable and dependable variable diminishes when the mediator is in the model. That means that, each of the constructs should show proof of a nonzero monotonic association with each other, but the relationship of the independent variable and dependent variable must decrease substantially upon adding the mediator as a predictor of the dependent variable [60].

The study expects attitude towards learning to mediate between HEdPERF on one hand and students' satisfaction and academic performance on the other. Examining the standard estimates of the mediation model, it is observed that the direct paths from HEdPERF to students' satisfaction is positive and statistically significant $(\beta=0.7486839 ; \mathrm{Z}=14.00 ; \mathrm{P}=0.000)$. The indirect path of HEdPERF through attitude towards learning to students' satisfaction is also positive and statistically significant $(\beta=0.1150935 ; Z=4.22 ; \mathrm{P}=0.000)$. The total effect for HEdPERF is also positive and statistically significant $(\beta=0.8637774 ; \mathrm{Z}=17.85$; $\mathrm{P}=0.000)$. As regards the standard estimates of the mediation model between HEdPERF and academic performance, it is observed that the direct paths from HEdPERF to academic performance is positive and statistically significant ( $\beta=$ 3,059,591; $\mathrm{Z}=5.34 ; \mathrm{P}=0.000$ ). The indirect path of HEdPERF through attitude towards learning to academic performance is also positive and statistically significant $(\beta=0.3247469 ; \mathrm{Z}=7.54 ; \mathrm{P}=0.000)$. The total effect for HEdPERF on academic performance is also positive and statistically significant $(\beta=630,706 ; \mathrm{Z}$ $=13.97 ; \mathrm{P}=0.000)$. Base on the assumption by [59] attitude towards learning partially mediate the relationships between HEdPERF on one hand, and students' satisfaction and academic performance on the other. This finding rejects $\mathrm{H}_{5}$.

The implication is that, HEdPERF as a measure of service quality on its own will impact positively and significantly on students' satisfaction and academic performance. There is also another way that students' satisfaction and academic performance can be enhanced; thus through students' attitude towards learning. Table 9 shows direct, indirect and total effect of HEdPERF on students' satisfaction and academic performance via attitude towards learning.

\subsection{Summary of Hypothesized Construct}

HEdPERF which is a measure of service quality positively and significantly

Table 9. Direct, indirect and total effects.

\begin{tabular}{lcccc}
\hline Path & $\begin{array}{c}\text { Direct Effect } \\
\text { (D) }\end{array}$ & $\begin{array}{c}\text { Indirect Effect } \\
(\mathrm{I})\end{array}$ & $\begin{array}{c}\text { Total Effect } \\
(\mathrm{D}+\mathrm{I})\end{array}$ & $\begin{array}{c}\text { Form of } \\
\text { Mediation }\end{array}$ \\
\hline $\mathrm{HEdPERF} \rightarrow \mathrm{ATL} \rightarrow \mathrm{SAT}$ & $0.7486839^{* *}$ & $0.1150935^{* *}$ & $0.8637774^{* *}$ & Partial \\
$\mathrm{HEdPERF} \rightarrow \mathrm{ATL} \rightarrow \mathrm{PERF}$ & $0.3059591^{* *}$ & $0.3247469^{* *}$ & $0.630706^{* *}$ & Partial \\
\hline $\begin{array}{l}\text { Note: ATL }=\text { Attitude towards learning; PERF }=\text { Academic Performance; SAT }=\text { Students' Satisfaction; } \\
\text { Significant. }\end{array}$
\end{tabular}


predict both students' satisfaction, academic performance and attitude towards learning and attitude towards learning also positively predicts students' satisfaction and academic performance. Attitude towards learning partially mediates the relationship between HEdPERF and students' satisfaction on one hand and HEdPERF and academic performance on the other. This implies that, HEdPERF on its own can impact on students' satisfaction and academic performance. However, if positive attitude towards learning are intensified, students' satisfaction and academic performance can also be realized. Table 10 presents summary of the hypothesized constructs.

\section{Conclusion}

This study has the objective to investigate the impact of HEdPERF on students' satisfaction and academic performance, and the mediating role of students' attitude towards learning. To achieve this objective, the research appraised all the measurement scales of the said constructs to determine their measurement value in the study context for theory and managerial practices. The study found that out of the HEdPERF 36 variables as developed by [4] 19 variables adequately measure service quality at Ghanaian private higher education sector. The study revealed that, the number of items under each of the 5 dimensions of HEdPERF was reduced. The non-academic aspect dimension items were reduced from 8 to 5. The rest of the reductions were in the areas of academic aspect, which reduced from 8 to 4 , reputation from 7 to 3 , access from 7 to 3 , and programme issues from 6 to 4. Three dimensions (academic aspects, reputation and programme issues) have positive and significant relationships with students' satisfaction and academic performance. Access has positive but no significant relationship with students' satisfaction and academic performance. On the contrary, non-academic aspect dimension has negative and no significant relationships with students' satisfaction and academic performance. The study again revealed that, HEdPERF has positive and statistical significant relationships with students' satisfaction, attitude towards learning and academic performance. Attitude towards learning also has positive and statistical significant relationships with students' satisfaction

Table 10. Summary of hypothesized construct.

\begin{tabular}{lc}
\hline \multicolumn{1}{c}{ Hypothesis } & \multicolumn{1}{c}{ Status } \\
\hline $\mathrm{H}_{1}$ Service quality has positive and significant impact on students' satisfaction. & Supported \\
$\mathrm{H}_{2}$ Service quality has positive and significant impact on academic performance. & Supported \\
$\mathrm{H}_{3}:$ Attitude towards learning positively and significantly affects academic performance. & Supported \\
$\mathrm{H}_{4}: \begin{array}{l}\text { Attitude towards learning has positive and significant relationship with students' } \\
\text { satisfaction }\end{array}$ & Supported \\
$\mathrm{H}_{5 \mathrm{a}}$ Attitude towards learning has full mediation effect on the relationship between & Rejected \\
$\mathrm{H}_{5 \mathrm{~b}} \quad \begin{array}{l}\text { Attitude towards learning has full mediation effect on the relationship between } \\
\text { service quality, and students' satisfaction }\end{array}$ & Rejected \\
\hline
\end{tabular}


and academic performance. As regards the mediation effect, attitude towards learning partially mediates between HEdPERF on one hand and students' satisfaction and academic performance on the other. This means that students' satisfaction and academic performance can be achieved through HEdPERF and/or through attitude towards learning.

\section{Managerial and Policy Implications}

The major conclusion from the study is that, for predictive purposes managers of higher education sector should focus on academic aspect, reputation, and programme issues to achieve students' satisfaction and academic performance. As this study has indicated negative relationship between non-academic aspect on one hand and students' satisfaction and academic performance on the other, managers of higher education institutions should formulate and implement non-academic policies that aim to improve students' satisfaction and academic performance. The direct effect of HEdPERF on student's satisfaction is greater than the indirect effect. This implies that managers of higher education can achieve better students' satisfaction through service quality than to use service quality to enhance attitude towards learning before improving students' satisfaction. On the other hand, the indirect effect of HEdPERF on academic performance is greater $(\beta=0.3247469 ; 0.000)$ than the direct effect $(\beta=0.3059591$; 0.000 ). This means that academic performance can be improved when service quality enhances attitude towards learning.

\section{Direction to Future Studies with Limitations}

This research has provided additional insight into HEdPERF, students' satisfaction, attitude towards learning, and academic performance. The negative relationship between non-academic aspect dimension and students' satisfaction and academic performance should be further investigated. The partial mediation role of attitude towards learning on the relationship between HEdPERF on one hand and students' satisfaction and academic performance on the other needs further research in different higher education context. Notwithstanding the new insight into HEdPERF, students' satisfaction, attitude towards learning and academic performance, caution is needed in generalizing the findings although considerable evidence of relative efficacy has been found in the modified constructs. The present study is limited to Ghanaian Private Universities based in Kumasi and the assertion needs to be validated by further studies in different University settings.

\section{References}

[1] Dabholkar, P.A. (1995) A Contingency Framework for Predicting Causality between Customer Satisfaction and Service Quality. In: Kardes, F.R. and Sujan, M., Eds., NA-Advances in Consumer Research, Vol. 22, Association for Consumer Research, Provo, 101-108.

[2] Ali, F., Zhou, Y., Hussain, K., Nair, P.K. and Ragavan, N.A. (2016) Does Higher 
Education Service Quality Effect Student Satisfaction, Image and Loyalty? A Study of International Students in Malaysian Public Universities. Quality Assurance in Education, 24, 70-94. https://doi.org/10.1108/QAE-02-2014-0008

[3] Athiyaman, A. (1997) Linking Student Satisfaction and Service Quality Perceptions: The Case of University Education. European Journal of Marketing, 31, 528-540. https://doi.org/10.1108/03090569710176655

[4] Abdullah, F. (2005) HEdPERF versus SERVPERF: The Quest for Ideal Measuring Instrument of Service Quality in Higher Education Sector. Quality Assurance in Education, 13, 305-328. https://doi.org/10.1108/09684880510626584

[5] Jain, R., Sinha, G. and Sahney, S. (2011) Conceptualizing Service Quality in Higher Education. Asian Journal on Quality, 12, 296-314.

https://doi.org/10.1108/15982681111187128

[6] Dužević, I., Čeh Časni, A. and Lazibat, T. (2015) Students' Perception of the Higher Education Service Quality. Croatian Journal of Education, 17, 37-67.

[7] Yavuz, M. and Gülmez, D. (2016) The Assessment of Service Quality Perception in Higher Education. Egitim ve Bilim, 41, 251-265.

[8] Marinho, S.V. and Poffo, G.D. (2016) Quality of Diagnosis in a Higher Education Institution: The Perception of the Academic Community. Avaliação: Revista da Avaliação da Educação Superior (Campinas), 21, 455-478. https://doi.org/10.1590/S1414-40772016000200008

[9] Croom, S. (2010) Introduction to Research Methodology in Operations Management. Researching Operations Management. Routledge, Abingdon-on-Thame, 56-97.

[10] Parasuraman, A., Zeithaml, V.A. and Berry, L.L. (1988) Servqual: A Multiple-Item Scale for Measuring Consumer PERC. Journal of Retailing, 64, 12.

[11] Knutson, R.L. (1991) Repertory of Shakespeare's Co. University of Arkansas Press, Fayetteville.

[12] Cronin, J.J. and Taylor, S.A. (1992) Measuring Service Quality: A Reexamination and Extension. The Journal of Marketing, 56, 55-68.

https://doi.org/10.2307/1252296

[13] Getty, J.M. and Thompson, K.N. (1994) A Procedure for Scaling Perceptions of Lodging Quality. Hospitality Research Journal, 18, 75-96. https://doi.org/10.1177/109634809401800206

[14] Icli, G. and Anil, N. (2014) The HEDQUAL Scale: A New Measurement Scale of Service Quality for MBA Programs in Higher Education. South African Journal of Business Management, 45, 31-43. https://doi.org/10.4102/sajbm.v45i3.129

[15] Abdullah, A.-M. (2011) Factors Affecting Business Students' Performance in Arab Open University: The Case of Kuwait. International Journal of Business and Management, 6, 146.

[16] Soutar, G. and McNeil, M. (1996) Measuring Service Quality in a Tertiary Institution. Journal of Educational Administration, 34, 72-82. https://doi.org/10.1108/09578239610107174

[17] Silva, D.S., Moraes, G.H.S.Md., Makiya, I.K. and Cesar, F.I.G. (2017) Measurement of Perceived Service Quality in Higher Education Institutions: A Review of HEdPERF Scale Use. Quality Assurance in Education, 25, 415-439. https://doi.org/10.1108/QAE-10-2016-0058

[18] Anderson, E.W. and Sullivan, M.W. (1993) The Antecedents and Consequences of Customer Satisfaction for Firms. Marketing Science, 12, 125-143. 
https://doi.org/10.1287/mksc.12.2.125

[19] Athanassopoulos, A., Gounaris, S. and Stathakopoulos, V. (2001) Behavioural Responses to Customer Satisfaction: An Empirical Study. European Journal of Marketing, 35, 687-707. https://doi.org/10.1108/03090560110388169

[20] Raghavan, S. and Ganesh, R. (2015) Addressing Service Quality to Increase Students' Satisfaction and Retention in Malaysian Private Higher Education Institutions. American Journal of Economics, 5, 243-250.

[21] Appiah-Adu, K. (1999) Marketing Effectiveness and Customer Retention in the Service Sector. Service Industries Journal, 19, 26-41. https://doi.org/10.1080/02642069900000028

[22] Rego, L.L., Morgan, N.A. and Fornell, C. (2013) Reexamining the Market Share-Customer Satisfaction Relationship. Journal of Marketing, 77, 1-20. https://doi.org/10.1509/jm.09.0363

[23] De Ruyter, K., Bloemer, J. and Peeters, P. (1997) Merging Service Quality and Service Satisfaction. An Empirical Test of an Integrative Model. Journal of Economic Psychology, 18, 387-406. https://doi.org/10.1016/S0167-4870(97)00014-7

[24] Brady, M.K. and Robertson, C.J. (2001) Searching for a Consensus on the Antecedent Role of Service Quality and Satisfaction: An Exploratory Cross-National Study. Journal of Business Research, 51, 53-60. https://doi.org/10.1016/S0148-2963(99)00041-7

[25] Sureshchandar, G., Rajendran, C. and Anantharaman, R. (2002) The Relationship between Service Quality and Customer Satisfaction-A Factor Specific Approach. Journal of Services Marketing, 16, 363-379. https://doi.org/10.1108/08876040210433248

[26] Bharwana, T.K., Bashir, M. and Mohsin, M. (2013) Impact of Service Quality on Customers' Satisfaction: A Study from Service Sector Especially Private Colleges of Faisalabad, Punjab, Pakistan. International Journal of Scientific and Research Publications, 3, 1-7.

[27] Mushtaq, I. and Khan, S.N. (2012) Factors Affecting Students Academic Performance. Global Journal of Management and Business Research, 12, 17-22.

[28] Hijazi, S.T. and Naqvi, S. (2006) Factors Affecting Students' Performance: A Case of Private Colleges. Bangladesh e-Journal of Sociology, 3, 1-10.

[29] Tho, L.M. (1994) Some Evidence on the Determinants of Student Performance in the University of Malaya Introductory Accounting Course. Accounting Education, 3, 331-340. https://doi.org/10.1080/09639289400000031

[30] Raychaudhuri, A., Debnath, M., Sen, S. and Majumder, B.G. (2010) Factors Affecting Students' Academic Performance: A Case Study in Agartala Municipal Council Area. Bangladesh e-Journal of Sociology, 7, 34-41.

[31] Saenz, T., Marcoulides, G.A., Junn, E. and Young, R. (1999) The Relationship between College Experience and Academic Performance among Minority Students. International Journal of Educational Management, 13, 199-207. https://doi.org/10.1108/09513549910278124

[32] Valentine, M.J. (2003) The Role of Satisfaction in the Retention and Performance of University Students.

[33] Fishbein, M. and Ajzen, I. (1975) Belief, Attitude, Intention and Behavior: An Introduction to Theory and Research.

[34] Ajzen, I. (2005) Attitudes, Personality, and Behavior. McGraw-Hill Education, London. 
[35] Baker, C. (1992) Attitudes and Language: Multilingual Matters.

[36] Wenden, A. (1991) Learner Strategies for Learner Autonomy. Prentice Hall, New York.

[37] Vaughan, G. and Hogg, M.A. (2005) Introduction to Social Psychology. Pearson Education, Melbourne.

[38] Fazal, S., Hussain, S., Majoka, M.I. and Masood, S. (2012) The Role of Study Skills in Academic Achievement of Students: A Closer Focus on Gender. Pakistan Journal of Psychological Research, 27, 37.

[39] Fishbein, M. and Ajzen, I. (2011) Predicting and Changing Behavior: The Reasoned Action Approach. Taylor \& Francis, Abingdon-on-Thames.

[40] Aiken, L.H., Clarke, S.P. and Sloane, D.M. (2002) Hospital Staffing, Organization, and Quality of Care: Cross-National Findings. Nursing Outlook, 50, 187-194. https://doi.org/10.1067/mno.2002.126696

[41] Osa-Edoh, G. and Alutu, A. (2012) A Survey of Students Study Habits in Selected Secondary Schools: Implication for Counselling. Current Research Journal of Social Sciences, 4, 228-234.

[42] Credé, M. and Kuncel, N.R. (2008) Study Habits, Skills, and Attitudes: The Third Pillar Supporting Collegiate Academic Performance. Perspectives on Psychological Science, 3, 425-453. https://doi.org/10.1111/j.1745-6924.2008.00089.x

[43] Sarwar, M., Bashir, M. and Alam, M. (2010) Study Attitude and Academic Achievement at Secondary Level in Pakistan. Journal of College Teaching \& Learning, 7, 55-60. https://doi.org/10.19030/tlc.v7i2.89

[44] Burke, L.A. and Williams, J.M. (2008) Developing Young Thinkers: An Intervention Aimed to Enhance Children's Thinking Skills. Thinking Skills and Creativity, 3, 104-124. https://doi.org/10.1016/j.tsc.2008.01.001

[45] Çetin, Ş. (2006) Establishment of the Profession of Teaching Attitude Scale (The Study for Validity and Confidence). The Journal of Industrial Arts Education Faculty of Gazi University, 18, 28-37.

[46] Harrell, K.D. (2000) Attitude Is Everything. Harper Audio.

[47] Lassen, S.R., Steele, M.M. and Sailor, W. (2006) The Relationship of School-Wide Positive Behavior Support to Academic Achievement in an Urban Middle School. Psychology in the Schools, 43, 701-712. https://doi.org/10.1002/pits.20177

[48] Alahmed, M., Yusof, A., Saidon, A., Borhannudin, A. and Prihadi, K. (2016) Moderation Role of Attitude on the Relationship between Participation in Competitive Sports and Academic Performance of Student-Athletes in Saudi Arabia. Springer, Berlin.

[49] Candeias, A. (1997) Attitudes toward School-An Exploratory Study with Pupils from Basic Education. Publications "University of Évora", Collection of Social and Human Sciences, Évora, Vol. 7.

[50] Stutely, R. (2003) Numbers Guide. Bloomberg Press, New York.

[51] Shapiro, E.S. and Kratochwill, T.R. (1988) Behavioral Assessment in Schools: Conceptual Foundations and Practical Applications. Guilford Press, New York.

[52] Tapia, M. and Marsh, G.E. (2004) An Instrument to Measure Mathematics Attitudes. Academic Exchange Quarterly, 8, 16-22.

[53] Bagozzi, R.P. and Yi, Y. (2012) Specification, Evaluation, and Interpretation of Structural Equation Models. Journal of the Academy of Marketing Science, 40, 8-34. https://doi.org/10.1007/s11747-011-0278-x 
[54] Fornell, C. and Larcker, D.F. (1981) Structural Equation Models with Unobservable Variables and Measurement Error: Algebra and Statistics. Journal of Marketing Research, 18, 382-388. https://doi.org/10.2307/3150980

[55] Bagozzi, R.P. and Yi, Y. (1988) On the Evaluation of Structural Equation Models. Journal of the Academy of Marketing Science, 16, 74-94.

https://doi.org/10.1007/BF02723327

[56] Hair, J.F., Black, W.C., Babin, B.J., Anderson, R.E. and Tatham, R.L. (1998) Multivariate Data Analysis. Prentice Hall, Upper Saddle River.

[57] Nuthana, P. and Yenagi, G.V. (2009) Influence of Study Habits, Self-Concept on Academic Achievement of Boys and Girls. Karnataka Journal of Agricultural Sciences, 22, 1135-1138.

[58] MacKinnon, D.P., Goldberg, L., Clarke, G.N., Elliot, D.L., Cheong, J., Lapin, A., et al. (2001) Mediating Mechanisms in a Program to Reduce Intentions to Use Anabolic Steroids and Improve Exercise Self-Efficacy and Dietary Behavior. Prevention Science, 2, 15-28. https://doi.org/10.1023/A:1010082828000

[59] Baron, R.M. and Kenny, D.A. (1986) The Moderator-Mediator Variable Distinction in Social Psychological Research: Conceptual, Strategic, and Statistical Considerations. Journal of Personality and Social Psychology, 51, 1173. https://doi.org/10.1037/0022-3514.51.6.1173

[60] Bolger, N. (1998) Data Analysis in Social Psychology. Handbook of Social Psychology, 1, 233-265. 